\title{
Mother-child Referencing of Environmental Print and its Relationship with Emergent Literacy Skills
}

\author{
Michelle M. Neumann ${ }^{1}$, Michelle Hood ${ }^{1,2}$, \& Ruth M. Ford ${ }^{1,2}$ \\ ${ }^{1}$ School of Applied Psychology, Griffith University, QLD 4222, Australia \\ ${ }^{2}$ Behavioral Basis of Health, Griffith Health Institute, Griffith University, QLD 4222, Australia
}




\begin{abstract}
Research Findings: Environmental print provides children with their earliest print experiences. This observational study investigated the frequency of mother-child environmental print referencing and its relationship with emergent literacy. Thirty-five mothers and their children (aged 3 - 4 years) were videotaped interacting in an environmental print-rich play setting. The frequency of environmental print referencing of letters and words was measured. Children were assessed on emergent literacy skills (letter name and sound knowledge, print concepts, phonological awareness, name and letter writing, environmental print reading). Sixty-nine percent of mothers referenced environmental print. After controlling for child age, home literacy teaching, and maternal education, greater maternal referencing of environmental print was positively related to print concepts and name and letter writing. Child environmental print referencing was positively related to name and letter writing as well as to maternal environmental print referencing. Mothers used a range of mediation strategies to support children's interactions with environmental print. Practice or Policy: Maternal referencing of environmental print may be a useful way to scaffold emergent literacy in young children.
\end{abstract}

Keywords: environmental print referencing, emergent literacy, mother-child interactions, maternal mediation strategies, preschoolers 


\section{Mother-child Referencing of Environmental Print and its Relationship with Emergent Literacy Skills}

Emergent literacy develops from birth as children build upon their literacy skills and knowledge through meaningful experiences with print (Goodman, 1986; Teale \& Sulzby, 1986; Whitehurst \& Lonigan, 1998). These skills are important precursors for future reading development (Australian Government, 2005; Snow, Burns, \& Griffin, 1998). In addition to shared storybook reading, a potentially important way that young children come to experience print is through shared interactions with environmental print (Enz, Prior, Gerard, \& Han, 2008; Neumann, Hood, Ford, \& Neumann, 2012; Vera, 2011). Environmental print is defined as surrounding non-continuous print that fulfills real-life functions and appears in a variety of fonts, shapes, sizes and generally in capital letters (e.g., Horner, 2005; Vukelich, Christie, \& Enz, 2008). Examples include labels and commercialized print on grocery products, toys, restaurant logos and street signs (e.g., Adams, 1990; Masonheimer, Drum, \& Ehri, 1984). Environmental print differs from other forms of print (e.g., newspaper, magazines, books, telephone directory) in that the context provides clues for its meaning (Masonheimer et al., 1984; McGee, Lomax, \& Head, 1988; Vukelich et al., 2008). While environmental print may also contain numerals and symbols (e.g., \$2), the current study focused on letters and words in environmental print.

Meaningful interactions with environmental print can occur during routine daily activities, play, or during interactions with parents (McGee \& Richgels, 1989; Teale, 1986). For example, Purcell-Gates (1996) observed that parent-child print related activities occurred around daily living routines (e.g., reading grocery product labels). Parents may therefore reference environmental print when caring for or playing with their child by actively pointing out these words and letters and these interactions may promote emergent literacy development (Gerard, 2004; Lass, 1982). Justice 
and Pullen (2003) noted that print referencing involves adult/parent use of both verbal (comments and questions e.g., that's the letter A; where is the word dog?) and non-verbal references (pointing to and tracking print with a finger). Some studies have shown that print referencing during storybook reading enhances print and word awareness in children (e.g., Justice \& Ezell, 2000; Justice \& Pullen, 2003). However, the extent to which environmental print referencing by parents supports emergent literacy requires further examination as knowledge about this type of referencing is limited.

Several case studies have documented that parents point out print in the environment and that children respond positively to this (e.g., Lass, 1982; McGee \& Richgels, 1989; Neumann, Hood, \& Neumann, 2009; Neumann \& Neumann, 2010; Sinclair \& Golan, 2002). For example, 2year-old Luc pointed out print in supermarket logos after his parents had previously referenced it (Sinclair \& Golan, 2002). Harste, Burke, and Woodward (1981) reported how a father pointed out a road sign "West 465" to his 3-year-old daughter and asked her what it said. Alison responded by saying "It says Daddy turn right to go to the zoo" (p 325). As the child read the sign logographically by using visual cues rather than letter-sound analysis skills (Frith, 1985), she was gaining meaning from the print which is an important component of emergent literacy (Whitehurst \& Lonigan, 1998). Although these case studies provide evidence of parent-child interactions with environmental print, they lack detail about the nature and frequency of these interactions. Teale (1986) and Purcell-Gates (1996) examined natural parent-child interactions with environmental print in larger participant samples of pre-schoolers $(N=25$ and $N=20$, respectively). Both studies showed that families engage with environmental print such as product labels in the home. However, information on the frequency of referencing environmental print letters or words by mothers and their children was not reported. Teale (1986) discussed the need for further investigation into the 
nature of these types of parent-child print interactions and how they affect emergent literacy development.

Another important issue to consider in the referencing of environmental print is the nature of the interactions themselves. Parent-child interactions with environmental print can be understood in terms of Vygotsky's (1978) socio-cultural perspective. Parents may scaffold literacy interactions with their children (Clarke-Stewart \& Beck, 1999; Dodici, Draper, \& Peterson, 2003; TrawickSmith \& Dziurgot, 2011; Vandermaas-Peeler, Nelson, Bumpass, \& Sassine, 2009). For instance, McGee and Richgels (1989) reported how a father had pointed to the $\mathrm{K}$ in $K$-Mart several times, after which his 3-year-old daughter began pointing to the letter $\mathrm{K}$ in the sign. Her father also scaffolded further learning opportunities by referencing other letters in environmental print. Neumann et al. (2009) described how a mother referred to individual letters in environmental print (e.g., cereal box labels) to help her child learn about letter names, shapes, and sounds. In addition, the mother encouraged her child to trace letters in the environmental print with his finger. When the child had mastered a letter, the mother no longer used the tracing strategy for that letter. Moreover, the child later initiated his own identification of the letter when he discovered them in environmental print.

Explicit guidance from a parent during shared literacy activities supports the development of emergent literacy skills (Bus, van IJzendoorn, \& Pelligrini, 1995; Sénéchal \& Le Fevre, 2002). Training parents to explicitly point to print during storybook reading increased 4-year-olds' memory of print concepts, word concepts and word segmentation abilities (Justice \& Ezell, 2000). Although several studies have investigated parent-child interactions with print during storybook reading (e.g., Bus et al., 1995; Justice \& Ezell, 2000), little work has examined interactions with environmental print and its relationship with emergent literacy. Moreover, while it is well 
documented that parents point out and read environmental print to their children during every day experiences (Lynch, 2008; Mason, 1980; Purcell-Gates, 1996; Teale, 1986), no studies to date have specifically examined environmental print referencing by mothers and their children to determine the frequency with which they reference individual letters and words in environmental print and how that is related to a broad range of emergent literacy skills, nor have they described different strategies mothers use to support children's interactions with environmental print.

The current study was exploratory and aimed to extend previous research on print interactions during storybook reading by documenting the frequency of interactions referencing environmental print and how this was related to the child's emergent literacy skills and to describe the nature of the strategies used by mothers when referencing environmental print. The frequency and the qualitative coding were used for different purposes. The frequency of references was used to determine if greater use of this resource is related to greater literacy development, whereas the qualitative coding was used to richly describe the sorts of interactions that mothers have with their children around environmental print.

All mother-child dyads were observed in the same print-rich play setting to provide control over the type and quantity of environmental print that they were exposed to and to eliminate potential distractions that would occur at home. Print-rich play settings have been used to replicate literacy contexts from the outside world in past research (e.g., Justice \& Pullen, 2003; Neuman \& Roskos, 1993; Vukelich, 1994) and enable the quantification of spontaneous and freely occurring behaviors (Irwin \& Bushnell, 1980). In the present study, the frequency of environmental print referencing by mothers and children was measured by observing verbal and non-verbal behaviors (e.g., Justice \& Ezell, 2000). Referencing of letters and words were examined separately as previous studies (e.g., McGee \& Richgels, 1989; Neumann et al., 2009) on mother-child interactions with 
environmental print did not provide information regarding the frequency with which environmental print letters as opposed to words are referenced. Children were also assessed on emergent literacy measures that are important precursors of conventional reading: letter name and sound knowledge, print concepts, phonological awareness, and name and letter writing, as well as environmental print reading (Whitehurst \& Lonigan, 1998). Child age, maternal education, and home literacy teaching activities were included as control measures. We controlled for home literacy teaching as opposed to non-teaching literacy activities (e.g., storybook reading) as we were interested in how environmental print referencing might be used as a teaching tool and how this related to emergent literacy. Finally, the types of environmental print maternal mediation strategies were described.

Neumann and Roskos (1993) examined adult-child interactions with environmental print ( $N$ $=177$ ) and found that adult mediation with environmental print in an enriched office play-setting scaffolded and enhanced preschool children's print knowledge. To gain a comprehensive view of how adults and young children used environmental print, they examined adult-child interactions with environmental print within representative play frames. After examining play frames that were focussed on adult-mediated environmental print interactions, Neuman and Roskos (1993) then classified their qualitative dialogues/descriptions by creating a typology of five interactive strategies (naturally used by adults to assist and extend the children's literacy activity and print knowledge). These strategies were a) labeling, b) demonstrating, c) direction-giving, d) extending, and e) feeding back. Neuman and Roskos (1993) emphasised the importance of collaborations and adult scaffolding of children's interactions with environmental print to support early literacy development. This typology was used to describe maternal environmental print strategies. 
The present study examined the following questions:

1) What is the frequency of mother and child referencing of letters and words in environmental print within an environmental print-rich setting? Based on prior case studies showing environmental print referencing (e.g., Lass, 1982; McGee \& Richgels, 1989), it was hypothesised that the majority of mothers and children would reference environmental print. Due to the real-life functions of environmental print, it was expected that words would be referenced more than letters.

2) Is the frequency of mother and child environmental print referencing of letters or words related to emergent literacy skills? Based on previous work on parent-child print interactions during storybook reading (Justice \& Ezell, 2000), it was hypothesised that environmental print referencing would be positively related to print concepts. Due to a paucity of prior research on mother-child environmental print interactions and other emergent literacy skills (e.g., early writing, phonological awareness), no specific hypotheses could be made regarding the relationship between the frequency of print referencing and these measures.

3) What types of maternal environmental print letter and word mediation strategies are most commonly used? It was expected that we would observe mothers using these types of strategies: a) labeling, b) demonstrating, c) direction-giving, d) extending, e) feeding back to support environmental print interactions; however, the most common strategy was to be determined. 


\section{Method}

\section{Participants}

The sample consisted of 35 mother-child dyads recruited through six preschools on the Gold Coast, Queensland, Australia. The preschools did not have any formal instruction in reading or writing, but did have informal play-based literacy activities (e.g., shared storybook reading, drawing, singing nursery rhymes). To be eligible to participate, children were required to have English as their main language and to obtain a minimum standard score of 80 on the Peabody

Picture Vocabulary Test $4^{\text {th }}$ Edition (PPVT-IV; Dunn $\&$ Dunn, 2007) to ensure typical development of receptive language skills. The final sample had a mean score of $106.51(S D=10.30$, Range $=84-$ 130) on the PPVT-IV. In addition, children with serious developmental problems as indicated by the parent questionnaire (e.g., speech, language, eyesight or hearing problems, or chronic ear infections) were not eligible to participate. One child was too shy to complete any of the assessments and two children had hearing problems and were excluded, resulting in the final sample of 35 children ( 15 boys, 20 girls $)$ with a mean age of 4.30 years $(S D=0.47$; Range $=3.36-4.98)$.

Most mothers were married or in a de facto relationship (91.4\%). Of the remainder, $2.9 \%$ were divorced or separated and $5.7 \%$ reported never being married or in a de facto relationship. Family socio-economic status (SES) was calculated using the Hollingshead 4-factor Index (Hollingshead, 1975) based on parental educational level and occupational status. The mean SES fell in the middle SES range of 40 to $54(M=51.26$; $S D=8.18$; range 34 - 63). Parents' highest education levels ranged from $10^{\text {th }}$ or $11^{\text {th }}$ grade to postgraduate training, with $14.3 \%$ of mothers and $2.9 \%$ of fathers being high school graduates, $37.1 \%$ of mothers and $20.0 \%$ of fathers having completed undergraduate degrees, and $17.1 \%$ of mothers and $5.7 \%$ of fathers having postgraduate training. The modal occupational status was professional for mothers (34.3\%) and associate 
professional for fathers (31.4\%). The majority of parents identified as Australian (63\% mothers, $65 \%$ fathers), with $22 \%$ of mothers and $17 \%$ of fathers identifying New Zealand heritage. Smaller numbers identified as English (6\% mothers, $6 \%$ fathers), European (3\% mothers, $9 \%$ fathers), or South African (6\% mothers, 3\% fathers).

\section{Materials}

Environmental print play setting. The environmental print play setting was constructed in the corner of a quiet room separate to the classrooms at each preschool to avoid distractions. The 2 $\mathrm{m} \times 2 \mathrm{~m}$ space was fitted with grocery play props. The food props consisted of 15 items of plastic play food (fruit/vegetables/bread) and 15 items of grocery products with print on the packaging (i.e., FROOT LOOPS, MILO, RICE BUBBLES, COCO POPS, NUTRI-GRAIN, CORN FLAKES, SHAPES, PICNIC, Lollipops, Weet-Bix, Icecream, Milk, Coca Cola, Pepsi, Eggs). In addition, there were four signs that had the names and prices of grocery items (CEREAL \$3, DRINKS \$2, FRUIT \$1, VEGES \$1) and there were three general grocery store signs (OPEN/CLOSED, EXIT, and GROCERY SHOP). Finally, the play setting was equipped with an additional two posters advertising products, shopping bags, wallets, toy cash register, play money, shopping basket, and shelving for the grocery items.

Emergent literacy measures. Each child was assessed on letter name and sound knowledge, print concepts, phonological awareness, name and letter writing, environmental print reading, and screening measure receptive vocabulary.

Letter name and sound knowledge. Twenty-six upper case letters were presented to children in random order, printed in black Century Gothic font size 72 on individual 8 x $8 \mathrm{~cm}$ white cards. Children were asked the name and sound of each letter. One point was given for each correct answer ( $\max =26$ each for name and sound scores). 
Concepts About Print test. (Clay, 2005). This test has good reliability (split half reliability of .84 - .89) and acceptable validity (.64 - .79; Brassard \& Boehm, 2007). Twenty items suitable for non-reading preschool aged children were used to assess awareness of and knowledge about print. The test was administered by reading a storybook (Stones; Clay, 2008) to the child while asking the questions. Nine of the 20 items (e.g., directionality, reading from left to right, where to start reading, discriminating a word from a letter, little versus big letters) showed acceptable internal consistency (Cronbach's $\alpha=.71$ ). Accordingly, the total score was based on those 9 items ${ }^{1}$ (max score $=9$ ).

Phonological awareness. Three tasks were used to assess phonological awareness. The rhyme detection test (Muter, Hulme, Snowling, \& Taylor, 1997) used four words presented in picture form. The target word was named by the researcher and the child was asked to point to one of three pictures, each of which was named, that rhymed with the target picture. There were three initial practice items on which corrective feedback and explanation was provided followed by 10 trials. The initial and final phoneme detection tests (Bowey, 1994) used a similar methodology. Four words were presented in picture form. Children were asked to identify the picture/word that started with the same sound as the target word (initial phoneme detection task) or to identify the picture/word that ended with the same sound as the target (final phoneme detection task). For each task, there were 2 practice trials with corrective feedback and explanation, followed by 10 test trials. Correct scores on the rhyme, initial, and final phoneme tasks were summed to form a total phonological awareness score $(\max =30)$. Internal consistency was acceptable (Cronbach's $\alpha=$ $.75)$.

\footnotetext{
${ }^{1}$ Since only 9 of 20 print concept items were used to generate an aggregate score this should be taken into consideration when interpreting this measure.
} 
Name writing. Children were asked to write their name. The name writing samples were scored globally using a 7-point scale adapted from Bloodgood (1999) where $0=$ no production, $1=$ random scribbling, $2=$ controlled scribbling, $3=$ random letter-like forms, $4=$ strings of nonphonetic conventional letters, $5=$ some correct letters, $6=$ generally correct with some letters backwards, and 7 = name written and spelled correctly. Using this global score ensured that the length of the child's name did not influence scores received.

Letter writing. Children were asked to write all the letters they knew in 60 seconds. If children finished early they were prompted to write more. Scoring was based on Gentry’s (2005) descriptors and samples where non-alphabetic writing includes marks, scribbles or non-letter-like forms and alphabetic writing consists of conventionally formed letters. Each conventionally formed letter was given one point (upper and lower case of the same letter were given one point each but repeated letters were counted once only). Incorrectly formed non-alphabetic letters, controlled and/or linear scribbling such as drawings, dots, circles, lines, random letter-like forms oriented incorrectly or back-to-front (i.e., pseudo-letters) were scored as zero. The number of conventional letters written was tallied to give a total letter writing score.

Environmental print reading. Following a similar methodology to Blair and Savage (2006) and Lomax and McGee (1987) environmental print words were selected based on common environmental print found in the local area. Parent suggestions of environmental print words helped in the selection of the words. These words were also similar to those used in previous environmental print studies (e.g., Horner, 2005; Masonheimer et al., 1984). All children were tested on the same 10 environmental print words (MILO, FROOT LOOPS, CORN FLAKES, RICE BUBBLES, NUTRI-GRAIN, PEPSI, STOP, LEGO, EXIT, SNICKERS). 
The items were presented in random order and in full context (e.g., on a cereal box). The researcher pointed to and ran a finger under the word asking, "What does this say?" Children scored two points for reading the item correctly (e.g., "Pepsi”), one point for a meaningful attempt (e.g., “drink" for Pepsi), and zero for an incorrect response $(\max =20)$.

\section{Control Measures}

Receptive vocabulary. The PPVT-IV (Dunn \& Dunn, 2007) was used to test children's receptive vocabulary. It provides normative data for 2.5 to over 90 years of age. The child selects one of four pictures that best represents a word spoken by the examiner. Dunn and Dunn (2007) reported high split-half reliabilities of around .94 .

Home literacy teaching. On the parent questionnaire, parents reported the frequency (on a 6-point scale from $1=$ never to $6=$ several times per day) with which they engaged the child in a variety of literacy teaching activities at home. This was included to control for potential influences of general literacy teaching practices on the emergent literacy skills. The nine items included teaching the child to read words, names and sounds of letters and to write/copy letters, words and their name. An overall score was created $(\max =54)$. Cronbach's $\alpha$ was .90 .

Demographic characteristics. The parent questionnaire included items regarding mother's age, parent's education level and occupational status, marital status, and main language in the home as well as child gender, age, and developmental history. Maternal education and child age were used as control measures in the analyses.

\section{Frequency of Mother and Child Environmental Print Referencing During the Play Session}

The print referencing criteria was adapted from Ezell and Justice (2000) and Justice and Ezell (2000). The frequency of explicit environmental print references by each mother and child during the 15-minute play session was counted (1 count per verbal or non-verbal reference) as 
detailed below. The frequency of references was used in the statistical analyses to examine the relationship between the frequency of environmental print referencing and emergent literacy skills.

For each of the 35 video play sessions spanning a 15-minute time-frame, transcripts of all environmental print-related utterances and behaviors were made for each mother and child dyad by the first author. When a mother or child attended to a letter or word in environmental print during the 15-minute play session using a verbal or non-verbal reference, this was coded as a reference (scored 1). The coding guidelines are detailed below. (See the Appendix for an example of the scoring of one mother-child dialogue).

- Verbal references included Comments (e.g., That's a letter M in MILO, That sign says OPEN); Questions (e.g., Can you see a D in that DRINKS sign? Which word says FRUIT?); or Requests (e.g., Show me where it says CORN FLAKES; Look at the word on that EXIT sign).

- Non-verbal references involved pointing to or tracking the word/letter with a hand or finger. For example, when pointing to print the mother or child's finger touched the environmental print and extended towards, on, or near the word or letter, or when tracking print the mother ran her finger along or underneath the word.

Behaviors resulting from general product handling were not scored if there was no specific reference to the print. For example, a mother saying "We need some Weet-Bix for breakfast" but not specifically referencing the word "Weet-Bix" on the box was considered general product handling and not environmental print referencing. If the environmental print consisted of more than one word (e.g., RICE BUBBLES) it was scored as one unless the participant specifically referred to each word separately. This scoring system yielded separate letter and word reference counts, as well as a total (letter plus word) environmental print referencing score for each mother and child. 


\section{Maternal Mediation Strategies}

Qualitative coding was used to describe strategies that mothers used to support letter and word interactions around environmental print and to determine which mediation strategy was most common. Individual play frames (a "play frame" is a unit of play that occurs in a certain location with a specific focus or interaction; Neuman \& Roskos, 1993) where mothers used environmental print to support their child's literacy were identified in each video transcript. Each play frame was classified into a letter or word interaction. Each of these transcripts was microanalysed and classified into Neuman and Rosko’s (1993) five adult mediation strategies.

Each mediation strategy was classified as follows (a) demonstrating, the mother shows the child how to complete a literacy task (e.g., the mother modeled how to sound out a word, pointed to a letter, or ran a finger under a word); (b) labeling, the mother labels environmental print (e.g., the mother pointed to the print saying, "That word says MILK" or labels a letter using its name or sound); (c) direction-giving, the mother directs the child to perform a specific task or asks a question that would lead to a literacy behavior (e.g., the mother says to the child, "Look at the sign" or asks the child what a word says or to name a letter); (d) extending, the mother expands on what the child already knows about the print by asking further questions about the print, or discussing the print's meaning (e.g., the mother says, "what other words start with that letter?"; "that word means...." (e) feeding back, the mother positively acknowledges or praises the child's literacy attempts (e.g., the mother says to her child, "Great job! You read the word MILK"). One play frame may contain more than one maternal strategy with each strategy observed given a score of 1 point. (See the Appendix for an example of the scoring of one mother-child dialogue).

All video sessions were initially scored by the first author. To determine the reliability of the environmental print referencing, 10 of the 35 video sessions were randomly selected for inter-rater 
reliability analysis. Using this number of sessions for inter-rater reliability is consistent with previous studies (e.g., Ezell \& Justice, 2000; Justice \& Ezell, 2000). The 10 video sessions were scored by a trained research assistant who was not otherwise involved in the study. Inter-rater reliabilities for these 10 video sessions were high; mother letter $r=1.0$, child letter $r=1.0$, mother word $r=.92$, child word $r=.88$. Due to the high reliability, the first author's scores for all video sessions were used.

\section{Procedure}

Approval for the study was granted by the university ethics committee. Parents were informed that the study was about how mothers play with their children and how this was related to their child's literacy development. Following informed consent, mothers completed the questionnaire. After this was completed, each mother-child dyad was asked to play in the grocery shop setting for 15 minutes using the instruction "Please play with your child for 15 minutes in this grocery shop setting”. Play settings and instructions were identical for all participants, although they occurred in the child's specific preschool. Mothers were not told that the play session was related to the use of environmental print in literacy learning nor were mothers instructed to refer to any of the print in the play setting. These instructions aimed to help ensure a more natural play by the mother-child dyads and to minimize demand characteristics. The researcher remained in the room to videotape the mother and child's interactions.

The child completed the literacy assessments on the same day as the play observation in a quiet room at the child's preschool. Each child was individually assessed by the first author on the emergent literacy measures as well as receptive vocabulary (PPVT; Dunn \& Dunn, 2007). Tests were completed in a random order to avoid systematic order effects. Testing sessions lasted approximately 30 minutes and children were provided with breaks during testing. Children were 
thanked with stickers at the completion of the assessments and returned to their normal classroom activities.

\section{Results}

\section{The Relationship between Frequency of Environmental Print Referencing and Emergent}

\section{Literacy}

Analysis of the frequency of environmental print referencing showed that $69 \%$ of mothers $(n$ $=24)$ and $37 \%(n=13)$ of children referenced environmental print. Of the total sample, $11 \%$ of mothers ( $n=4 ; 2$ with daughters and 2 with sons) and $8 \%$ of children ( 2 girls and 1 boy) referenced letters within environmental print. A higher percentage of mothers $(66 \%, n=23 ; 15$ with daughters and 8 with sons) and children (37\%, $n=13 ; 11$ girls and 2 boys) referenced environmental print words. The majority of references by the mothers and children were of grocery signs (e.g., Fruit sign; $57 \%$ ) followed by references to labels on grocery products (e.g., Weet-Bix; 15\%), cash register labels (e.g., Accept; 11\%), and shop posters (e.g., Paddle Pop; 10\%) with least referencing to general shop signs (e.g., open/closed; 7\%).

Due to the small number of references to letters, overall environmental print referencing scores were calculated for each mother and child by combining letter and word references. Table 1 shows descriptive statistics for the frequency of environmental print referencing by mothers and children, emergent literacy skills, and home literacy teaching. The distributions of each variable were examined prior to correlational analyses. Maternal environmental print referencing scores, letter sound knowledge, and letter writing were positively skewed. A square root transformation was applied to normalize these distributions. Child environmental print referencing scores were not able to be transformed to normality due to severe floor effects. Therefore, children were categorized 
as referencers (coded $1, n=13$ ) or non-referencers ( $\operatorname{coded} 0, n=22)$. Gender was also a categorical variable $(0=$ male, $1=$ female $)$.

Table 1

Descriptive Statistics for Environmental Print Referencing and Emergent Literacy

\begin{tabular}{llll}
\hline Measure & Mean & $S D$ & Range \\
\hline Maternal environmental print referencing & 3.74 & 4.69 & $0-18$ \\
Child environmental print referencing & 0.80 & 1.69 & $0-8$ \\
Letter name $(\max 26)$ & 11.40 & 9.40 & $0-26$ \\
Letter sound $(\max 26)$ & 3.49 & 5.07 & $0-22$ \\
Print concepts $(\max 9)$ & 3.66 & 1.94 & $0-9$ \\
Phonological awareness $(\max 30)$ & 12.03 & 5.02 & $5-23$ \\
Name writing $(\max 7)$ & 4.71 & 2.23 & $1-7$ \\
Letter writing & 3.65 & 4.35 & $0-15$ \\
Environmental print reading $(\max 20)$ & 7.86 & 3.39 & $2-15$ \\
Home literacy teaching $(\max 54)$ & 37.20 & 9.42 & $13-52$ \\
\hline
\end{tabular}

Partial correlations between maternal environmental print referencing and emergent literacy skills, after controlling for child's age, maternal education, and home literacy teaching, are shown in Table 2. Maternal environmental print referencing was significantly and positively correlated with print concepts and name and letter writing. Higher frequency of environmental print referencing by mothers was associated with children scoring higher on print concepts, being more skilled at writing their name, and being able to correctly write more letters. There were no significant correlations between environmental print referencing in the play setting and reports of maternal teaching of literacy at home.

Due to children's environmental print referencing in the play setting being converted to a categorical measure, ANCOVAs were used to compare referencers and non-referencers on emergent literacy measures. Child age, maternal education, and home literacy teaching were entered as covariates to control for their influences in these analyses as well. There was a significant effect 
for name writing such that children who referenced environmental print in the play setting scored higher $(M=5.44, S D=0.32)$ than children who did not reference environmental print $(M=4.28$, $S D=0.24), F(1,30)=8.09, p=.008, \eta_{\mathrm{p}}{ }^{2}=.21$. Only age was a significant covariate, $p<.001 . \mathrm{A}$ similar significant effect emerged for letter writing, $F(1,30)=8.76, p=.006, \eta_{\mathrm{p}}{ }^{2}=.23$. Age was the only significant covariate in this analysis, $p<.001$. Referencers wrote significantly more letters $(M=2.06, S D=0.26)$ than did non-referencers $(M=1.06, S D=0.20)$. The children who referenced environmental print in the play setting also had mothers who referenced significantly more environmental print in that setting $(M=2.31, S D=0.33)$ than did children who did not reference environmental print $(M=0.97, S D=0.25), F(1,30)=10.21, p=.003, \eta_{\mathrm{p}}{ }^{2}=.25$. No covariates were significant in this analysis. There were no significant differences between child referencers and nonreferencers on any other measures.

Table 2

Partial Correlations between Maternal Environmental Print Referencing and Emergent Literacy Skills Controlling for Child Age, Home Literacy Teaching, and Maternal Education

\begin{tabular}{llllllll}
\hline Variable & 1 & 2 & 3 & 4 & 5 & 6 & 7 \\
\hline 1. Letter Name & - & & & & & & \\
2. Letter Sound Sqrt & $.50^{* *}$ & - & & & & & \\
3. Print Concepts & -.03 & .18 & - & & & & \\
4. Phonological Awareness & .14 & $.56^{* *}$ & -.08 & - & & & \\
5. Name Writing & .19 & .06 & .20 & -.10 & - & & \\
6. Letter Writing Sqrt & .12 & .04 & .07 & -.08 & $.72^{* *}$ & - & \\
7. EP Reading & .03 & .08 & .10 & $.30^{*}$ & -.19 & -.20 & - \\
8. Maternal EP Referencing Sqrt & .20 & .11 & $.30^{*}$ & -.04 & $.50 * *$ & $.36^{*}$ & -.09 \\
\hline
\end{tabular}

Note. Sqrt $=$ Square Root (square root transformation was used to normalise skewed distributions), $\mathrm{EP}=$ Environmental Print.

$* p<.05 ; * * p<.01$ 
To investigate the relationship between gender and child environmental print referencing, a chi-square contingency test was used (12 boys did not reference and 3 boys did; 10 girls did not reference and 10 girls did). There was a marginal trend toward a relationship between gender and environmental print referencing; however, this did not reach significance, $\chi^{2}(1, N=35)=3.30, p=$ .069. The trend was toward more boys in the non-referencing group than would be expected by chance.

\section{Maternal Mediation Strategies}

A total of 81 play frames that consisted of maternal mediation using environmental print were identified. These were classified into interactions with (1) Words (a total of 206 mother-child word interactions: 66 Demonstrating, 70 Labeling, 53 Direction Giving, 13 Extending, and 4 Feeding back) and (2) Letters (a total of 46 mother-child letter interactions: 13 Demonstrating, 12 Labeling, 14 Direction Giving, 4 Extending, and 3 Feeding back).

The most common word mediation strategies were labeling (34\%), demonstrating (32\%), and direction giving (26\%). The least common word strategies observed were extending (6\%), and providing positive feedback comments (2\%). A similar pattern of results was found when the letter referencing strategies were examined. The most common letter mediation strategies were direction giving (30\%), demonstrating (28\%), and labeling (26\%). The least common letter strategies observed were extending (9\%) and providing a positive feedback comment (7\%). Examples of these maternal mediation strategies are shown in Table 3 and 4. 
Table 3

\section{Maternal Word Mediation Strategies in the Play Setting}

\begin{tabular}{ll}
$\begin{array}{l}\text { Word Mediation } \\
\text { Strategies }\end{array}$ & Transcript Examples \\
\hline Demonstrating & $\begin{array}{l}\text { [The mother pointed and ran her finger under the word ACCEPT on the cash register and the } \\
\text { child looked at it] } \\
\text { Mother: "That says there was enough money on the credit card to pay". } \\
\text { [The child pointed to the word on the cash register with his finger] }\end{array}$ \\
\hline Labeling & The mother points to the MILO label on the cereal box and says to her child "that says MILO". \\
\hline Direction-giving & $\begin{array}{l}\text { The mother looks at the open/closed signs and says to her child: } \\
\text { Mother: "Look the shop is closed you better turn the sign around because the sign says closed, } \\
\text { we are open". }\end{array}$ \\
\hline Extending & $\begin{array}{l}\text { Mother: "What's this sign?" [The mother pointed to the FRUIT \$1 sign] } \\
\text { Child: "Same one". [The child pointed to the sign] } \\
\text { Mother: "Yes it's the same, what does it mean?" } \\
\text { Child: "Dollar". }\end{array}$ \\
\hline Mother: "How much are the bananas? Let's have a look at the FRUIT sign". \\
Child: "one dollar". [The child looks at the sign]. \\
Mother: "correct, good girl!" \\
*Note: there are two maternal mediation strategies in this example (feeding back and direction- \\
giving)
\end{tabular}

Table 4

Maternal Letter Mediation Strategies in the Play Setting

\begin{tabular}{|c|c|}
\hline $\begin{array}{l}\text { Letter Mediation } \\
\text { Strategies }\end{array}$ & Transcript Examples \\
\hline Demonstrating & $\begin{array}{l}\text { [The mother pointed to the first letter on the SHAPES biscuit box] } \\
\text { Mother: "Do you know this letter? What is it?" } \\
\text { Child: "S" (letter name). } \\
\text { Mother: "The word says SHHH..." [The mother pointed to the next letter] } \\
\text { Mother: "The H behind the S makes it be quiet - it says SH" }\end{array}$ \\
\hline Labeling & $\begin{array}{l}\text { Mother: "What sound?" [The mother pointed to the W on the Weet-Bix box] } \\
\text { Child: "Da, da". } \\
\text { Mother: "Wuh, Wuh". } \\
\text { Child: "Wuh, Wuh". }\end{array}$ \\
\hline Direction-giving & $\begin{array}{l}\text { Mother: "Buy me something with a letter R in it so we can buy something with your name. So } \\
\text { tell me whenever you see an R". } \\
\text { Child: "I found it". [The child looks around at the signs and pointed to the R in the FRUIT sign]. }\end{array}$ \\
\hline Extending & $\begin{array}{l}\text { Mother: "Can you see where it says on, that says off, and that says cancel C, C for cancel". } \\
\text { Mother: "C for..., who else has got a C?" } \\
\text { Child: "Carl". }\end{array}$ \\
\hline *Feeding back & $\begin{array}{l}\text { Mother: "What does drinks start with?" [The mother pointed to the sign] } \\
\text { Child: "D, and it's two dollars." [The child looked at the sign] } \\
\text { Mother: "What does it finish with, what's the last letter? } \\
\text { Child: "S" } \\
\text { Mother: "Well done!" } \\
\text { *Note: there are two maternal mediation strategies in this example (feeding back and direction- } \\
\text { giving) }\end{array}$ \\
\hline
\end{tabular}




\section{Discussion}

The present study examined the relations between the frequency of environmental print referencing and children's emergent literacy skills by documenting the spontaneous use of environmental print by 35 mother-child dyads in a controlled, environmental print-rich play setting. Extending previous research, we also controlled for child age, maternal education, and home literacy teaching activities, thereby providing a stringent test of these relations. Referencing of environmental print letters and words was recorded separately for both mothers and children. Moreover, we administered a comprehensive set of measures of emergent literacy skills (i.e., letter name and sound knowledge, print concepts, phonological awareness, name and letter writing, environmental print reading). Finally, we conducted an exploration of maternal mediation strategies (i.e., demonstrating, labeling, directing-giving, extending, and feeding back) for both letters and words.

The results showed that a majority of mothers $(69 \%)$ but a minority of children $(37 \%)$ made spontaneous references to environmental print words and letters. This is consistent with previous case studies that have reported parents referencing environmental print on signs and labels (Lass, 1982; McGee \& Richgels, 1989; Neumann et al., 2009). Referencing of words was much more frequent than referencing of letters by both mothers and children. Purcell-Gates (1996) also observed little letter referencing at home by families compared to word referencing. Similarly, in other studies focused on storybook print, it has been found that adults rarely reference letters or words to children during storybook reading (Ezell \& Justice, 1998; Phillips \& McNaughton, 1990) unless trained (Ezell \& Justice, 2000; Justice \& Ezell, 2000).

While it must be acknowledged in the present study that mothers may have engaged in more print-related talk than would normally occur in their natural environment because they were 
informed the study was about maternal play and children's literacy development, no instructions were given to mothers to use environmental print to support literacy. Furthermore, mothers did not engage their child in singing the alphabet song, which might have been expected if they were especially primed to the idea of play promoting literacy development. Generally, their referencing of the environmental print was in the context of playing grocery shop rather than being explicitly used to "teach" or demonstrate their child's literacy skills. Therefore, there are no strong reasons to suggest that the present results were affected by mothers' expectancies.

Importantly, the frequency of maternal environmental print referencing was positively related to children's name and letter writing and print concepts. Child environmental print referencing was also positively related to name and letter writing as well as to maternal print referencing. These correlations were robust even after controlling for the effects of age and broader enrichment as gauged by maternal education and home literacy activities. Although little research has examined maternal environmental print referencing and letter writing, the positive relationship observed in the present investigation is consistent with two prior case studies in which a mother's referencing of environmental print at home fostered her child's early writing (Neumann et al., 2009; Neumann \& Neumann, 2010). The current study shows that greater frequency of maternal as well as child environmental print referencing during play is associated with more advanced letter writing skills. When mothers refer their child to environmental print during meaningful daily activities, children might learn to visually attend to the shapes of individual letters that, in turn, might help them remember how to shape certain letters. In addition, children might also use environmental print to copy letters and words during daily activities (e.g., writing a shopping list or greeting card), which may foster letter shaping and word writing skills (Chan, Juan, \& Lai Foon, 2008). As mothers referenced print more frequently than children and this referencing predicted early writing, 
it is reasonable to assume that this maternal behavior serves to scaffold children's behavior and learning.

The present findings also suggest that environmental print referencing has the potential to support children's name writing which was related to the frequency of environmental print referencing by both mothers and children. Previous studies have examined the use of children's personal names in the environment (e.g., on lockers and labels) and found that children learn their names through reading them in context (Levin \& Ehri, 2009; Share \& Gur, 1999). Our results suggest that children who reference a range of words and letters in environmental print are more capable of writing their name than those who do not. Similarly, they have mothers who also reference words and letters in the environment. This indicates that referencing letters in environmental print, especially if they are similar to the elements of a child's name (e.g., the shape and sound of letters) may support children's name identification and production.

Maternal referencing of environmental print was positively associated with children's print concepts. This suggests that this type of print referencing may help children develop concepts about letters versus words and left-to-right directionality of print. As Justice and Ezell (2000) found that training parents to reference print during home storybook reading resulted in a significant increase in children's print concepts, it is possible that such training with environmental print referencing may have a similar effect.

No relationships were found between either maternal or child environmental print referencing and letter knowledge, phonological awareness, or environmental print reading. Mothers and children mainly referenced whole words and few referenced elements in words (i.e., letters by their names, linked sounds and symbols together, or discussed letter sounds within words) which may explain this result. In fact, due to the small number of letter references, a combined score for 
frequency of referencing letters and words had to be used. Furthermore, explicit parent teaching of letters may be needed for children to gain alphabetic knowledge (e.g., Hood, Conlon, \& Andrews, 2008), such as drawing children's attention to letters in environmental print that have special meaning (e.g., W for Weet-Bix...there's a W in your name). Our results show that parents do not spontaneously do that as frequently as referencing whole words and that may explain our null result. Similarly, Justice and Ezell (2000) found no significant effect on the children's alphabet knowledge with parents who were trained to use print referencing at the word or sentence level during storybook reading. In the current study, mothers also did not focus on the phonological components of environmental print (e.g., talking about words that rhymed with environmental print words). Like alphabetic knowledge, phonological awareness requires more explicit instruction that environmental print does not seem to spontaneously elicit (Adams, 1990).

The lack of a relationship with children's ability to read environmental print may have resulted because mothers mainly referenced environmental print to achieve their goals in the play rather than focusing on teaching the environmental print words. Learning to identify environmental print words could depend upon how explicitly the interaction focuses on helping children recognise the word. However, regular maternal referencing of environmental print words during meaningful daily experiences has the potential to enhance environmental print reading (McGee \& Richgels, 1989). For example, by saying, “That sign says STOP, so let's stop here”, children could learn to read the word "stop". Furthermore, a focus on the meaning of environmental print may be more developmentally appropriate for younger children who gain their meaning from contextual cues rather than older children who rely more on letter-sound skills. For those older children, more explicit reference to letters and sounds in environmental print words may potentially foster print decoding skills. 
A positive relationship was found between the frequency of maternal and child environmental print referencing. This relationship suggests that parents play an important role in modeling environmental print referencing behaviors to their children, which, in turn, may increase children's interactions with the print. Thus, richer joint environmental print experiences may occur through maternal strategies that help scaffold children's own interactions with print. Children might then learn to use these strategies to support their own interactions with print; for example, by using environmental print to guide their early writing attempts. It is, of course, also possible that childinitiated interactions encouraged parent mediation, but the higher frequency of maternal-initiated references than child-initiated references suggest that maternal referencing was the driving force.

We also examined the mediation strategies mothers used when referencing environmental print. Mothers used similar strategies when referencing letters or words with the most common being demonstrating, labeling, and direction giving. In contrast, use of extending strategies such as discussing the meaning of a word or asking further questions about the print were not widely observed. This suggests that mothers could benefit from being guided in using strategies to enhance their child's knowledge about the meaning and function of words or printed symbols. Environmental print is a rich literacy resource to help children make meaning and extend their understanding of print (e.g., Harste et al., 1981; McGee \& Richgels, 1989). Providing positive feedback following the child's literacy attempts, such as encouraging children with positive comments (e.g., "well done”) was also rare. Interestingly, one mother gained her child's attention and extended learning by tracing the dollar symbol (\$) on a grocery shop sign with her finger whilst saying its name and asking her child what the print said and meant. Furthermore, this mother provided her child with a positive feedback comment that encouraged her daughter to attend to and interact further with the print. This tactile technique of tracing elements within environmental print 
such as letters and numerals has also been reported in previous case studies (Neumann et al., 2009; Neumann \& Neumann, 2012). Such a multisensory approach may provide another scaffolding strategy to help children actively attend to and engage with environmental print letters and words.

\section{Limitations and Directions for Further Research}

The present study observed typically developing English-speaking pre-school aged children from middle SES families. Future research is required to extend the present findings to mothers and children from a wider range of ages, developmental levels, and backgrounds because other populations may show differences in maternal mediation strategies. For example, families in nonEnglish speaking cultures may differ in their mediation strategies due to the alphabetic script used (e.g., Chinese characters differ in form to English letters and words). In addition, conducting studies in home settings would provide evidence of how parents and their children reference environmental print letters and words during daily activities. In contrast to the print-rich play context used in the present research, further studies may use settings from the child's home environment, such as the kitchen or child's bedroom.

Testing the effects of directing children's attention to the letters in environmental print as a strategy to foster alphabet knowledge is an important issue for future research. It is possible that the maternal strategies observed in the present study may have a role in supporting emergent literacy development. For example, maternal labeling of environmental print letters may result in the growth of letter knowledge and print concepts could be fostered by demonstrating to a child how to interact with the print (e.g., running a finger under a word from left to right) and by giving directions (e.g., "find me a word in that sign that has the letter A in it"). However, the current study was observational in nature and as such is limited by not being able to infer such cause-effect relationships. An intervention approach is required in which a group of children experience explicit 
maternal mediation strategies and are compared to a control group. A recent preschool intervention study showed that environmental print referencing of letters and words by an adult instructor enhanced emergent literacy skills (e.g., letter sound knowledge, letter writing and print concepts; Neumann, Hood, \& Ford, 2012). Therefore, the potential benefits of environmental print referencing can be explored further by manipulating parents' referencing of environmental print to examine its effects on emergent literacy.

A more fine grained analysis of the role of maternal mediation strategies used to support children's interactions with environmental print is required. The present results showed that not all mothers referenced environmental print words and letters and some types of maternal mediation strategies were used infrequently (e.g., extending and feeding back). As a result, it was not possible to conduct meaningful correlational analyses between maternal mediation and emergent literacy skills. Future research may minimize this problem by observing a larger sample of mother-child dyads interact over a longer time period in different environmental print rich settings.

It was observed that during play mothers followed their child's lead during interactions with environmental print. However, it is important to note that some maternal environmental print referencing may have interrupted what children wanted to pursue in their play. Therefore, it is recommended that parents be encouraged to maintain their child's flow of play and be led by childinitiated interactions with environmental print. This may help ensure that environmental print referencing is meaningful and occurs in context during authentic experiences.

\section{Conclusion}

This study showed that mothers used a range of environmental print strategies when interacting with their child during play. They used spontaneous teachable moments to facilitate their child's exploration of letters and words in meaningful ways; however, not all mothers referenced 
environmental print. As the frequencies of maternal and child environmental print referencing were related to name and letter writing, even after controlling for age and home enrichment, the findings suggest that environmental print has an important role to play in emergent literacy, particularly emergent writing. Further, the finding that maternal referencing was related to print concepts indicates that this freely available print could be used to foster knowledge about letters versus words and other print conventions such as directionality. Coaching parents to draw children's attention to environmental print, particularly to personally relevant words and letters embedded in the print, and to discuss its meaning and function may help foster emergent literacy in young children. Further work using an evidence-based parent-child intervention program would help clarify the effects and any long-term benefits of environmental print referencing in emergent literacy development. 


\section{References}

Adams, M. J. (1990). Beginning to read: Thinking and learning about print. Cambridge, MA: MIT Press.

Australian Government. (2005). National inquiry into the teaching of literacy: Teaching reading, report and recommendations (Publication No. 064277577 X). Canberra, Australian Capital Territory: Author.

Blair, R., \& Savage, R. (2006). Name writing but not environmental print recognition is related to letter-sound knowledge and phonological awareness in pre-readers. Reading and Writing: An Interdisciplinary Journal, 19, 991-1016.

Bloodgood, J. W. (1999). What's in a name? Children's name writing and literacy acquisition. Reading Research Quarterly, 34, 342-367.

Bowey, J. A. (1994). Phonological sensitivity in novice readers and nonreaders. Journal of Experimental Child Psychology, 58, 135-159.

Brassard, M. R., \& Boehm, A. E. (2007). Preschool assessment: Principles and practices. New York, NY: Guildford Press.

Bus, A. G., van IJzendoorn, M. H., \& Pelligrini, A. D. (1995). Joint book reading makes success in learning to read: A meta-analysis on intergenerational transmission of literacy. Review of Educational Research, 65, 1-21.

Chan, L., Zi Juan, C., \& Lai Foon, C. (2008). Chinese preschool children's literacy development: From emergent to conventional writing. Early Years: An Interdisciplinary Journal, 28, 135148. 
Clarke-Stewart, K. A., \& Beck, R. J. (1999). Maternal scaffolding and children's narrative retelling of a movie story. Early Childhood Research Quarterly, 14, 409-434.

Clay, M. M. (2005). An observation survey of early literacy development. Auckland, NZ: Heinemann.

Clay, M. M. (2008). Stones. Northshore, NZ: Pearson.

Dodici, B. J., Draper, D. C., \& Peterson, C. A. (2003). Early parent-child interactions and early literacy development. Topics in Early Childhood Special Education, 23, 124-136.

Dunn, L. M., \& Dunn, D. M. (2007). The Peabody Picture Vocabulary Test (4 ${ }^{\text {th }}$ ed.). Bloomington, MN: NCS Pearson.

Enz, B. J., Prior, J., Gerard, M. R., \& Han, M. (2008). Exploring intentional instructional uses of environmental print in preschool and primary grades. In A. DeBruin-Parecki (Ed.), Effective early literacy practice: Here's how, here's why (pp. 15-24). Baltimore, MD: Paul. H. Brookes.

Ezell, H. K., \& Justice, L. M. (1998). A pilot investigation of parent questions about print and pictures to preschoolers with language delay. Child Language Teaching and Therapy, 14, $273-278$

Ezell, H. K., \& Justice, L. M. (2000). Increasing the print focus of adult-child shared book reading through observational learning. American Journal of Speech Language Pathology, 9, 36-47.

Frith, U. (1985). Beneath the surface of developmental dyslexia. In K. Patterson., J. Marshall \& M. Coltheart (Eds.), Surface dyslexia: Neuropsychological and cognitive studies of phonological reading. (pp. 301-330). London, UK: Erlbaum. 
Gentry, J. R. (2005). Instructional techniques for emerging writers and special needs students at kindergarten and grade 1 levels. Reading and Writing Quarterly, 21, 113-134.

Gerard, M. (2004). What's a parent to do? : Phonics and other stuff. Childhood Education, 80, 159-160.

Goodman, Y. (1986). Children coming to know literacy. In W. H. Teale \& E. Sulzby (Eds.), Emergent literacy: Writing and reading (pp. 1-14). Norward, NJ: Ablex.

Harste, J. C., Burke, C. L., \& Woodward, V. A. (1981). Examining our assumptions: A transactional view of literacy and learning. Research in the Teaching of English. 18, 84-108.

Hollingshead, A. B. (1975). The four-factor index of social status. Unpublished manuscript, Department of Sociology, Yale University, New Haven, USA.

Hood, M., Conlon, E., \& Andrews, G. (2008). Preschool home literacy practices and children's literacy development: A longitudinal analysis. Journal of Educational Psychology, 100, 252-271.

Horner, S. L., (2005). Categories of environmental print: All logos are not created equal. Early Childhood Education Journal, 33, 113-119.

Irwin, M., \& Bushnell, M. M. (1980). Observational strategies for child study. New York, NY: Holt, Rinehart and Winston.

Justice, L. M., \& Ezell, H. K. (2000). Enhancing children's print and word awareness through home-based parent intervention. American Journal of Speech-Language Pathology, 9, 257269.

Justice, L. M., \& Pullen, P. C. (2003). Promising interventions for promoting emergent literacy skills: Three evidence-based approaches. Topics in Early Childhood Special Education, 23, 99-113. 
Lass, B. (1982). Portrait of my son as an early reader. The Reading Teacher, 36, 20-28.

Levin, I., \& Ehri, L. C. (2009). Young children's ability to read and spell their own and classmates names: The role of letter knowledge. Scientific Studies of Reading, 13, 249-273.

Lomax, R. G., \& McGee, L. M. (1987). Young children's concepts about print and reading: Toward a model of word reading acquisition. Reading Research Quarterly, 22, 237-256.

Lynch, J. (2008). Engagement with print: Low-income families and Head Start children. Journal of Early Childhood Literacy, 8, 151-175.

Mason, J. M. (1980). When do children begin to read: an exploration of four year old children's letter and word reading competencies. Reading Research Quarterly, 15, 203-227.

Masonheimer, P. E., Drum, P. A., \& Ehri, L. C. (1984). Does environmental print identification lead children into word reading? Journal of Reading Behavior, 16, 257-271.

McGee, L. M., Lomax, R.G., \& Head, M. H. (1988). Young children's written language knowledge: What environmental print and functional print reading reveals. Journal of Reading Behavior, 20, 99-118.

McGee, L. M. \& Richgels, D. J. (1989). “K is Kristen's”: Learning the alphabet from a child's perspective. The Reading Teacher, 43, 216-225.

Muter, V., Hulme, C., Snowling, M., \& Taylor, S. (1997). Segmentation, not rhyming, predicts early progress in learning to read. Journal of Experimental Psychology, 65, 370-396.

Neuman, S. B., \& Roskos, K. (1993). Access to print for children of poverty: Differential effects of adult mediation and literacy-enriched play settings on environmental and functional print tasks. American Educational Research Journal, 30, 95-122.

Neumann, M. M., Hood, M., \& Neumann, D. L. (2009). The scaffolding of emergent literacy skills in the home environment: A case study. Early Childhood Education Journal, 36, 313-319. 
Neumann, M. M., \& Neumann, D. L. (2010). Parental strategies to scaffold emergent writing skills in the pre-school child within the home environment. Early Years: An International Journal of Research and Development, 30, 79-94.

Neumann, M. M., Hood, M., Ford, R. M., \& Neumann, D. L. (2012). The role of environmental print in emergent literacy. Journal of Early Childhood Literacy, 12, 231-258.

DOI: $10.1177 / 1468798411417080$

Neumann, M. M., \& Neumann, D. L. (2012). The role of idiomorphs in emergent literacy. Childhood Education, 88, 23-29.

Neumann, M. M., Hood, M., \& Ford, R. (2012). Using environmental print to enhance emergent literacy and print motivation. Reading and Writing: An Interdisciplinary Journal. DOI 10.1007/s11145-012-9390-7.

Phillips, G., \& McNaughton, S. (1990). The practice of storybook reading to preschool children in mainstream New Zealand families. Reading Research Quarterly, 25, 196-212.

Purcell-Gates, V. (1996). Stories, coupons, and the TV guide: Relationships between home literacy experiences and emergent literacy knowledge. Reading Research Quarterly, 31, 406-428.

Sénéchal, M., \& Le Fevre, J. (2002). Parental involvement in the development of children's reading skill: a five year longitudinal study. Child Development, 73, 445-460.

Share, D. L. \& Gur, T. (1999). How reading begins: A study of preschoolers' print identification strategies. Cognition and Instruction, 17, 177-213.

Sinclair, A., \& Golan, M. (2002). Emergent Literacy: A case-study of a two-year-old. Early Child Development and Care, 172, 555-572.

Snow, C. E., Burns, S., \& Griffin, P. (1998). Preventing reading difficulties in young children. Washington, DC: National Academy Press. 
Teale, W. H. (1986). Home background and young children's literacy development. In W.H. Teale \& E. Sulzby (Eds.), Emergent literacy: Writing and reading (pp. 173-206). Norwood, NJ: Ablex.

Teale, W. H. \& Sulzby, E. (1986). Emergent literacy: Writing and reading. Norwood, NJ: Ablex. Trawick-Smith, J., \& Dziurgot, T. (2011). 'Good-fit' teacher-child play interactions and the subsequent autonomous play of preschool children. Early Childhood Research Quarterly, $26,110-123$.

Vandermaas-Peeler, M., Nelson, J., Bumpass, C., \& Sassine, B. (2009). Social contexts of development: Parent-child interactions during reading and play. Journal ofEarly Childhood Literacy, 9, 295-317.

Vera, D. (2011). Using popular culture print to increase emergent literacy skills in one high-poverty urban school district. Journal of Early Childhood Literacy, 11, 307-330.

Vukelich, C. (1994). Effects of play interventions on young children's reading of environmental print. Early Childhood Research Quarterly, 9, 153-170.

Vukelich, C., Christie, J., \& Enz, B. (2008). Helping young children learn language and literacy: Birth through kindergarten. Boston, MA: Pearson.

Vygotsky, L. S. (1978). Mind and society: The development of higher mental processes. Cambridge, MA: Harvard University Press.

Whitehurst, G. J., \& Lonigan, C. J. (1998). Child development and emergent literacy. Child Development, 69, 848-872. 


\section{Appendix}

\section{Example of Scoring the Frequency of Environmental Print Referencing}

\section{and Maternal Mediation (Total Duration of Video Play Session = 15 minutes)}

\begin{tabular}{|c|c|c|c|}
\hline $\begin{array}{l}\text { Time of } \\
\text { interaction } \\
\text { (Minutes) }\end{array}$ & Transcript Example of Mother-Child Dyad \#2 & $\begin{array}{l}\text { Environmental } \\
\text { Print } \\
\text { Referencing } \\
\text { Score }\end{array}$ & $\begin{array}{l}\text { Maternal Mediation } \\
\quad \text { Strategy }\end{array}$ \\
\hline 0.35 & $\begin{array}{l}\text { Mother reads each sign to child and says "Fruit } \mathbf{\$ 1} \text {, } \\
\text { Veges } \mathbf{\$ 1} \text {, Cereal } \mathbf{\$ 3} \text {, Drinks } \mathbf{\$ 2 "} \text {. }\end{array}$ & $\begin{array}{l}\text { Mother } \\
\text { word } \\
\text { references }\end{array}$ & Labeling \\
\hline 0.46 & $\begin{array}{l}\text { Mother gains the child's attention and reads the sign } \\
\text { and says "grocery shop" and "what's up there?" } \\
\text { Mother points to the closed sign and turns the sign } \\
\text { over and says "open"...."closed". Mother asks "is the } \\
\text { shop open or closed?" and the child looks at sign and } \\
\text { says, "open". }\end{array}$ & $\begin{array}{l}4 \text { Mother } \\
\text { word } \\
\text { references } \\
1 \text { Child word } \\
\text { reference }\end{array}$ & $\begin{array}{l}\text { Labeling, Direction- } \\
\text { giving }\end{array}$ \\
\hline 1.05 & $\begin{array}{l}\text { Mother says there's another sign there as she points to } \\
\text { the EXIT sign. Then she asks the child "what's it } \\
\text { say?" The child does not reply so the mother says, "it } \\
\text { says EXIT - to go out". }\end{array}$ & $\begin{array}{l}2 \text { Mother } \\
\text { word } \\
\text { references }\end{array}$ & $\begin{array}{l}\text { Demonstrating, } \\
\text { Direction-giving, } \\
\text { Labeling }\end{array}$ \\
\hline 5.28 & $\begin{array}{l}\text { Mother reads the print on the back of the FROOT } \\
\text { LOOPS box and says, "Can you find } 22 \text { FROOT } \\
\text { LOOPS hidden in the jungle?" The child then counts } \\
\text { them on the box. }\end{array}$ & $\begin{array}{l}1 \text { Mother } \\
\text { word } \\
\text { reference }\end{array}$ & Labeling \\
\hline 7.39 & $\begin{array}{l}\text { Child looks at the back of the COCO POPS cereal box } \\
\text { and says, "there's a game on the back of this too". The } \\
\text { mother asks "what does it say?" The child does not } \\
\text { reply. The mother reads the print on the cereal box } \\
\text { "What action packed adventure can you count how } \\
\text { many cool things Coco is doing". Mother and child } \\
\text { point out and describe the pictures on the box saying } \\
\text { "He's banging the drums, surfing, going in a cave, } \\
\text { swinging on a rope like Tarzan". }\end{array}$ & $\begin{array}{l}1 \text { Mother } \\
\text { word } \\
\text { reference }\end{array}$ & $\begin{array}{l}\text { Direction-giving, } \\
\text { Labeling }\end{array}$ \\
\hline
\end{tabular}

